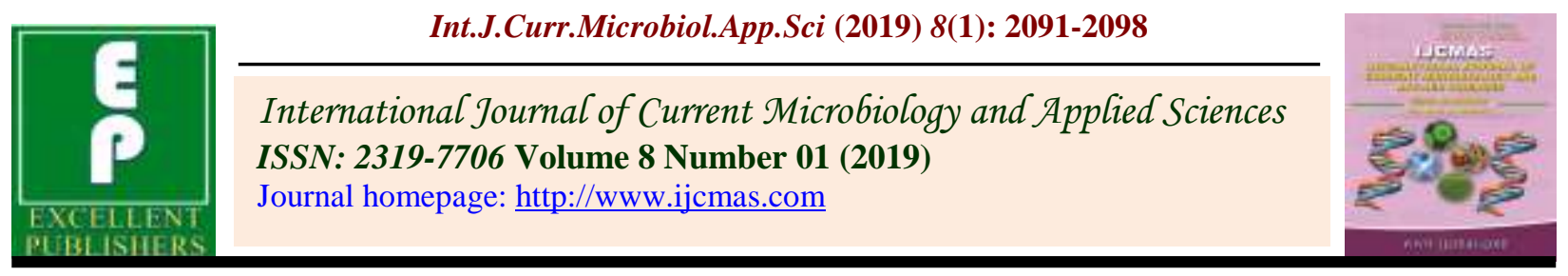

Original Research Article

https://doi.org/10.20546/ijcmas.2019.801.219

\title{
Effect of Calcium Nitrate on Propagation of LA Hybrid Lilies through Scaling
}

\author{
Anu Bala*, Puja Sharma, S.R. Dhiman and Y.C. Gupta \\ Department of Floriculture and Landscape Architecture, Dr. YSP University of Horticulture \\ and Forestry, Nauni, Solan, Himachal Pradesh, 173230, India \\ *Corresponding author
}

\section{Keywords}

LA hybrid lilies, Scaling, Calcium Nitrate, Cocopeat

Article Info

Accepted:

14 December 2018 Available Online: 10 January 2019

\begin{abstract}
A B S T R A C T
The present study was carried out to work out the "Effect of calcium nitrate on propagation of LA hybrid lilies through scaling". The experiment was laid out in a Completely Randomized Design (factorial) consisting of three cultivars and six calcium nitrate doses $\left(0,5,10,15,20\right.$ and $\left.25 \mathrm{~g} / \mathrm{m}^{2}\right)$. Among the cutivars, maximum bulblet multiplication was shown by 'UHFS LA Lily Collection 1' (2.59) followed by 'Batistero' (2.48) and 'Frans Hals' (2.32), respectively. Among the different calcium nitrate doses, $10 \mathrm{~g} / \mathrm{m}^{2}$ calcium nitrate dose gave best results for per cent sprouting (76.03\%), minimum days taken for sprouting (102.00 days), sprout length $(9.60 \mathrm{~cm})$, fresh weight of bulblet/scale $(1.69 \mathrm{~g})$, bulblet diameter $(9.32 \mathrm{~mm})$ and propagation index $(125.69 \%)$ when supplied to the scales in ten equal split doses in liquid form. However, for obtaining higher number of leaves/scale (6.38) and maximum multiplication (2.90 bulblets/scale) calcium nitrate application at the rate of $20 \mathrm{~g} / \mathrm{m}^{2}$ supplied to these scales proved to be most effective treatment. The interaction between cultivars and calcium nitrate doses has shown variable responses. Percent sprouting was observed maximum in 'Frans Hals' (77.14 \%) with 15 $\mathrm{g} / \mathrm{m}^{2}$ and $25 \mathrm{~g} / \mathrm{m}^{2}$ calcium nitrate and in 'UHFS LA Lily Collection 1' (77.14\%) with 10 $\mathrm{g} / \mathrm{m}^{2}$, maximum sprout length $(10.18 \mathrm{~cm})$, number of bulblets $/ \mathrm{scale}(3.01)$ and bulblet diameter $(9.77 \mathrm{~mm})$ in cultivar 'UHFS LA Lily Collection 1' with $10 \mathrm{~g} / \mathrm{m}^{2}$ and maximum number of leaves/scale (7.03) in cultivar 'Batistero' with $25 \mathrm{~g} / \mathrm{m}^{2}$ calcium nitrate dose.
\end{abstract}

\section{Introduction}

Lilium is one of the leading cut flower on the basis of sale in the world and very popular due to its richness and variety of colours. About $76 \%$ of the total world lily bulb production takes place in the Netherlands, with the area of 4,280 hectares and with the number of 2.2 billion lily bulbs, of which 2.1 billion $(96 \%)$ are used as starting material for cut flower cultivation within the Netherlands and abroad. To bring new appearance in white flowering Easter lilies, L. longiflorum have been crossed with Asiatic hybrid lilies to develop the new series of LA hybrids. These new hybrids have outward facing flowers of different colours. LA hybrids have become very popular these days. They are valued for their good vase life, availability in wide range of colours, wider adaptability and ease of 
cultivation. In India suitable climatic conditions for lilium cultivation have been identified in different pockets of the country. In Himachal Pradesh Lahaul, Kullu and Chail area in Solan are highly suitable for its multiplication.

Presently in India lilium bulbs for flower production are imported from other countries. Netherlands is the chief exporter and supplier. Therefore to reduce the cost of bulb and to meet out the increasing demand of flowers throughout the year by providing sufficient planting material, there is an urgent need to develop cheaper multiplication techniques indigenously to increase the bulblet production.

Asexual propagation of Lilium species can be accomplished by separation of stem bulbils or bulblets, division of bulbs and scaling. Another advanced method of propagation is through tissue culture. Propagation of lilium through scaling is the most effective, cheap and rapid method for multiplication, however the commercial sized bulbs are obtained in 34 years. The present experiment was, therefore, planned to study the effect of calcium nitrate on propagation of LA hybrid lilies through scaling. The experiment was carried out with the objective to find out optimum dose of calcium nitrate for multiplication through scaling in LA hybrid lilies.

\section{Materials and Methods}

Study on the propagation of three LA hybrid lily cvs. viz. 'Batistero', 'Frans Hals' and 'UHFS LA Lily Collection 1'through scaling was done at the experimental farm of the Department of Floriculture and Landscape Architecture, Dr. Y.S. Parmar University of Horticulture and Forestry, Nauni, Solan, Himachal Pradesh during November, 2013 to June, 2014.

\section{Plant material}

Uniform sized (14/16), healthy and precooled bulbs of three LA hybrid lily cvs. viz. Batistero, Frans Hals and UHFS LA Lily Collection 1 were selected for the studies. These were procured from Sheel BiotechLtd., Pune in November, 2013.

\section{Propagation medium}

In the present investigations cocopeat was used as propagation medium. Cocopeat bricks were soaked in water and then thoroughly washed in running water so that phenols could be removed by draining out the extra water. The medium was treated with fungicidal solution Mancozeb (0.25 \%) and Carbendazim $(0.1 \%)$ before use.

\section{Scaling}

The outermost two whorls in the bulb scales were selected for the experimentation. The individual scales were excised from the mother bulb with the help of a sharp sterile blade in such a way so that a small portion of basal plate remains attached to it. Rotten, broken and scales without basal plate were discarded. Average fresh weight of the scales was recorded. The detached scales were then disinfected by dipping them in fungicidal solution of Mancozeb $(0.25 \%)$ and Carbendazim $(0.1 \%)$ for one hour. These scales were kept in shade to drain out the excess solution. A quick dip was given to the basal end of the scale in NAA 500 ppm solution before planting.

\section{Planting of scales}

Planting of scales was done in plastic trays of size $36 \mathrm{~cm} \times 27 \mathrm{~cm} \times 7 \mathrm{~cm}$ provided with drainage holes. These trays were filled with prepared moistened cocopeat. The scales were then planted in such a way so that $2 / 3^{\text {rd }}$ 
portion of the scale remain embedded in the medium. The scales were planted at a distance of $2.5 \mathrm{~cm}$ in 7 rows accommodating 70 scales in a tray. Immediately after planting the scales were drenched with Mancozeb $(0.25 \%)$ and Carbendazim $(0.1 \%)$ which was repeated at 15 days interval for two months to avoid rotting of scales. The trays were maintained in propagation chamber. Optimum moisture level was maintained in medium by spraying water depending on the requirement.

\section{Fertilizer application}

Application of Calcium nitrate (Laboratory grade; $\mathrm{N} 25 \%$ and $\mathrm{Ca} 8.1 \%$ ) in solution form was started after 60 days of planting. Fertilizer was applied in 10 split doses at 15 days interval variable with the treatment. Application of Calcium nitrate was supplemented with phosphorus and potassium at $20 \mathrm{~g} / \mathrm{m}^{2}$ each which is supplied through phosphoric acid $3.84 \mathrm{ml} / \mathrm{m}^{2}$ and Multi-K 4.44 $\mathrm{g} / \mathrm{m}^{2}$. The bulblets were harvested when the $75 \%$ foliage turned yellow. Overall, the experiment consisting of 6 treatment combinations and three cultivars was conducted in completely randomized design (factorial). Observations on various vegetative and bulblet parameters recorded were subjected to analysis of variance.

\section{Results and Discussion}

Results revealed that per cent sprouting differed significantly among cultivars and calcium nitrate doses. Maximum sprouting $(75.55 \%)$ recorded in cultivar 'Frans Hals' was found to be at par with scale sprouting in 'UHFS LA Lily Collection 1' (75.00\%) and minimum $(74.04 \%)$ sprouting was recorded in 'Batistero' (Table 1). Variation in per cent sprouting among cultivars might be due to the genotypic differences. Similar findings have also been reported by Matsuo and Arisumi (6) in Lilium longiflorum cultivars; Singh (12) in
Asiatic cultivars, Sharma et al., (11) in Oriental lilies and Lyngdoh (5) in LA hybrid lilies and variation in days to corm sprouting in different gladiolus genotypes have also been reported by Safiullah and Ahmed (9) and Nair and Shiva (7).

Among calcium nitrate doses maximum scale sprouting (76.03 \%) was recorded with 10 $\mathrm{g} / \mathrm{m}^{2}$ application (Table 1 ). Interaction (Table 2) effect of cultivars with calcium nitrate doses shows that 'Frans Hals' maximum per cent sprouting $(77.14 \%)$ was recorded with calcium nitrate $15 \mathrm{~g}$ and $25 \mathrm{~g} / \mathrm{m}^{2}$, in cultivar 'UHFS LA Lily Collection 1' (77.14 \%) with $10 \mathrm{~g} / \mathrm{m}^{2}$ and in cultivar 'Batistero', maximum scale sprouting $(75.71 \%)$ was observed with calcium nitrate applied at $5 \mathrm{~g} / \mathrm{m}^{2}$.

Days taken for sprouting also differed significantly due to different treatments. Earliest sprouting (105.56 days) was recorded in cultivar 'UHFS LA Lily Collection 1' was, found to be at par with time taken for sprouting in cultivar 'Frans Hals' (107.28 days). Days taken for sprouting, however found maximum in cultivar 'Batistero' (109.17 days) (Table 1). Such variation among cultivars may be attributed to their genetic make-up. Similar results on differences on scale sprouting has also been emphasized by Matsuo and Arisumi (6). Among calcium nitrate doses, earliest sprouting (102.00 days) recorded with 10 $\mathrm{g} / \mathrm{m}^{2}$ calcium nitrate applied to scales. Early germination (up to 12 days after sowing) was promoted following treatment with $\mathrm{Ca}\left(\mathrm{NO}_{3}\right)_{2}$ and $\mathrm{KNO}_{3}$ has also been reported by Jong Won et al., (2).

Table 1 also reveals that among the cultivars maximum sprout length $(9.01 \mathrm{~cm})$ was recorded in 'UHFS LA Lily Collection 1'. Similar results with respect to length of sprout were recorded in 'Batistero' $(8.90 \mathrm{~cm})$ and minimum sprout length $(8.34 \mathrm{~cm})$ was 
observed in cultivar 'Frans Hals'. Data also shows that application of calcium nitrate at all the levels had a significant effect on sprout length of scales as compared to control. Maximum sprout length $(9.60 \mathrm{~cm})$ was, however, obtained when calcium nitrate was applied to the scales at the rate of $10 \mathrm{~g} / \mathrm{m}^{2}$. It is also evident from the data that optimum level of calcium nitrate varies with cultivars (Table 2). Maximum sprout length $(10.18 \mathrm{~cm})$ was recorded in cultivar 'UHFS LA Lily Collection 1',in cultivar 'Batistero' (10.10 $\mathrm{cm})$ when calcium nitrate was applied to the scales at $10 \mathrm{~g} / \mathrm{m}^{2}$, and in 'Frans Hals' (9.33 $\mathrm{cm})$ when calcium nitrate was given at the rate $15 \mathrm{~g} / \mathrm{m}^{2}$ to the scales. Our results are in close confirmity with Treder (13) in oriental lily 'Star Gazer' and Karimi et al., (3), they have concluded that optimum dose of calcium nitrate varies with cultivars and the best growth in Asiatic cv. 'Navona' and LA cv. 'Fangio'was observed at two different calcium nitrate levels i.e. 1.5 and $2 \mathrm{mM}$, respectively.

Data (Table 1) also shows that number of leaves per scale varied with cultivars. Maximum number of leaves/scale (6.13) recorded in cultivar 'Batistero' were found to be at par with 'UHFS LA Lily Collection 1' (5.93) and minimum number of leaves/scale (5.79) were recorded in cultivar 'Frans Hals'.Variable number of leaves/plants have also been observed in field experiment on different Asiatic lily cultivars by Rani et al., (8) and in scaling of Oriental lily cultivars by Sharma et al., (11). Data depicts an increasing trend in number of leaves/scale with increasing the calcium nitrate dose upto 20 $\mathrm{g} / \mathrm{m}^{2}$, with maximum number of leaves/scale (6.38) obtained when calcium nitrate was applied at $20 \mathrm{~g} / \mathrm{m}^{2}$. Choi et al., (1) have also stated that various lily cultivars have different optimum tissue nutrient levels which should be adjusted to ensure maximum growth and flower quality. It is also evident from Table 2 that maximum number of leaves/scale (7.03) were also observed in cultivar 'Batistero' when calcium nitrate was applied at $25 \mathrm{~g} / \mathrm{m}^{2}$, in cultivar 'Frans Hals' maximum number of leaves/scale (6.54) were obtained with calcium nitrate at $20 \mathrm{~g} / \mathrm{m}^{2}$ and in 'UHFS LA Lily Collection 1' maximum number of leaves/scale (6.45) recorded with $15 \mathrm{~g} / \mathrm{m}^{2}$ application of calcium nitrate.

The cultivars under study varied significantly for the production of bulblets per scale (Table 1) with maximum bulblets (2.59) observed in cultivar 'UHFS LA Lily Collection 1' it was, however, found to be at par with number of bulblets/scale (2.48) obtained in cultivar 'Batistero'. Results indicated that reproductive ability depended almost entirely on cultivar. Our results are supported by Krause (4) who studied the reproductive ability of some Lilium longiflorun varieties. Similar findings have also been reported by Matsuo and Arisumi (6) in Lilium longiflorum cultivars; Singh (12) in Asiatic cultivars, Sharma et al., (11) in Oriental lilies and Lyngdoh (5) in LA hybrid lilies. Among different calcium nitrate doses, maximum number of bulblets/scale (2.90) observed with $20 \mathrm{~g} / \mathrm{m}^{2}$ application of calcium nitrate to the scales. Interaction (Table 2) effect of cultivars with calcium nitrate doses shows that maximum number of bulblets/scale (3.01) were observed in cultivar 'UHFS LA Lily Collection 1' when supplied with $10 \mathrm{~g} / \mathrm{m}^{2}$ calcium nitrate and in 'Batistero'(2.99) and 'Frans Hals' (2.78) maximum number of bulblets/scale obtained with calcium nitrate at $20 \mathrm{~g} / \mathrm{m}^{2}$.

Bulblet size was observed maximum (9.34 $\mathrm{mm}$ in diameter) in cultivar 'UHFS LA Lily Collection 1' and minimum bulblet diameter $(8.14 \mathrm{~mm})$ was found in cultivar 'Batistero' (Table 1). The varietal differences in bulblet size during scaling of different types of lilies has been reported earlier also by Singh (12); 
Sharma et al., (11); Lyngdoh (5). Among different calcium nitrate doses, maximum bulblet size $(9.32 \mathrm{~mm})$ was observed when 10 $\mathrm{g} / \mathrm{m}^{2}$ calcium nitrate was given to the scales.

Interaction (Table 2) effect of cultivars with calcium nitrate doses shows that maximum bulblet diameter $(9.77 \mathrm{~mm})$ was recorded in cultivar 'UHFS LA Lily Collection 1', in
'Frans Hals' maximum bulblet size $(9.39 \mathrm{~mm})$ and in 'Batistero' maximum bulblet diameter $(8.81 \mathrm{~mm})$ recorded with $10 \mathrm{~g} / \mathrm{m}^{2}$ application of calcium nitrate respectively. Seyedi et al., (10) found that $6 \mathrm{mM}$ calcium produced maximum height of the plant, stem diameter, procreative height, number of buds, flower diameter and longevity of cut flowers in Asiatic hybrid lilium cv. 'Tresor'.

Table.1 Effect of cultivars and calcium nitrate doses on propagation of lilies through scaling

\begin{tabular}{|c|c|c|c|c|c|c|c|c|}
\hline $\begin{array}{l}\text { Characters } \\
\text { Treatments }\end{array}$ & $\begin{array}{c}\text { Per } \\
\text { cent } \\
\text { sprouti } \\
\text { ng }(\%)\end{array}$ & $\begin{array}{l}\text { Days } \\
\text { taken for } \\
\text { sproutin } \\
\text { g }\end{array}$ & $\begin{array}{l}\text { Sprout } \\
\text { length } \\
(\mathrm{cm})\end{array}$ & $\begin{array}{l}\text { Number } \\
\text { of } \\
\text { leaves/sc } \\
\text { ale }\end{array}$ & $\begin{array}{c}\text { Number } \\
\text { of } \\
\text { bulblets/ } \\
\text { scale }\end{array}$ & $\begin{array}{l}\text { Bulblet } \\
\text { diameter } \\
(\mathbf{m m})\end{array}$ & $\begin{array}{c}\text { Fresh } \\
\text { weight of } \\
\text { bulblet } \\
\text { (s)/scale }\end{array}$ & $\begin{array}{c}\text { Propagati } \\
\text { on index } \\
(\%)\end{array}$ \\
\hline \multicolumn{9}{|l|}{ Cultivars (V) } \\
\hline Batistero $\left(V_{1}\right)$ & $\begin{array}{c}74.04 \\
(8.61)^{*}\end{array}$ & 109.17 & 8.90 & 6.13 & 2.48 & 8.14 & 1.55 & 110.67 \\
\hline Frans Hals $\left(V_{2}\right)$ & $\begin{array}{l}75.55 \\
(8.69)\end{array}$ & 107.28 & 8.34 & 5.79 & 2.32 & 8.63 & 1.57 & 117.66 \\
\hline $\begin{array}{l}\text { UHFS LA Lily } \\
\text { Collection } 1\left(\mathbf{V}_{\mathbf{3}}\right)\end{array}$ & $\begin{array}{l}75.00 \\
(8.66)\end{array}$ & 105.56 & 9.01 & 5.93 & 2.59 & 9.34 & 1.46 & 112.39 \\
\hline CD at $5 \%$ & 0.06 & 2.17 & 0.43 & 0.21 & 0.16 & 0.28 & 0.07 & 5.53 \\
\hline \multicolumn{9}{|c|}{ Calcium nitrate doses $(\mathrm{T})$} \\
\hline $0 \mathrm{~g} / \mathrm{m}^{2}\left(\mathrm{~T}_{1}\right)$ & $\begin{array}{l}73.01 \\
(8.54)\end{array}$ & 109.33 & 8.24 & 5.45 & 2.12 & 8.40 & 1.32 & 97.94 \\
\hline $5 \mathrm{~g} / \mathrm{m}^{2}\left(\mathrm{~T}_{2}\right)$ & $\begin{array}{l}74.91 \\
(8.65)\end{array}$ & 109.22 & 8.39 & 5.78 & 2.25 & 8.47 & 1.48 & 110.07 \\
\hline $10 \mathrm{~g} / \mathrm{m}^{2}\left(\mathrm{~T}_{3}\right)$ & $\begin{array}{l}76.03 \\
(8.72)\end{array}$ & 102.00 & 9.60 & 5.88 & 2.58 & 9.32 & 1.69 & 125.69 \\
\hline $15 \mathrm{~g} / \mathrm{m}^{2}\left(\mathrm{~T}_{4}\right)$ & $\begin{array}{l}75.24 \\
(8.67)\end{array}$ & 105.89 & 9.11 & 6.13 & 2.62 & 8.82 & 1.63 & 121.66 \\
\hline $20 \mathrm{~g} / \mathrm{m}^{2}\left(\mathrm{~T}_{5}\right)$ & $\begin{array}{l}75.08 \\
(8.67)\end{array}$ & 108.89 & 8.67 & 6.38 & 2.90 & 8.66 & 1.59 & 118.85 \\
\hline $25 \mathrm{~g} / \mathrm{m}^{2}\left(\mathrm{~T}_{6}\right)$ & $\begin{array}{l}74.92 \\
(8.65)\end{array}$ & 108.67 & 8.47 & 6.10 & 2.29 & 8.55 & 1.45 & 107.23 \\
\hline CD at $5 \%$ & 0.09 & 3.08 & 0.62 & 0.30 & 0.23 & 0.40 & 0.10 & 7.82 \\
\hline
\end{tabular}

Figures in parenthesis shows the square root transformed value 
Table. 2 Interaction effect of cultivars and calcium nitrate doses on propagation of lilies through scaling

\begin{tabular}{|c|c|c|c|c|c|c|c|c|}
\hline $\begin{array}{l}\text { Characters } \\
\text { Treatments }\end{array}$ & $\begin{array}{c}\text { Per cent } \\
\text { sprouting } \\
(\%)\end{array}$ & $\begin{array}{l}\text { Days taken } \\
\text { for } \\
\text { sprouting }\end{array}$ & $\begin{array}{c}\text { Sprout } \\
\text { length }(\mathrm{cm})\end{array}$ & $\begin{array}{l}\text { Number of } \\
\text { leaves/scale }\end{array}$ & \begin{tabular}{|c|} 
Number of \\
bulblets/scale
\end{tabular} & $\begin{array}{c}\text { Bulblet } \\
\text { diameter } \\
(\mathbf{m m})\end{array}$ & $\begin{array}{c}\text { Fresh } \\
\text { weight of } \\
\text { bulblet } \\
\text { (s)/scale }\end{array}$ & $\begin{array}{c}\text { Propagatic } \\
\text { n index } \\
(\%)\end{array}$ \\
\hline \multicolumn{9}{|c|}{ Interaction $(\mathbf{V} \times \mathbf{T})$} \\
\hline $\mathbf{V}_{1} \mathbf{T}_{1}$ & $\begin{array}{l}72.37 \\
(8.51)^{*}\end{array}$ & 111.33 & 8.31 & 5.33 & 2.09 & 7.65 & 1.31 & 93.33 \\
\hline $\mathbf{V}_{1} \mathbf{T}_{2}$ & $\begin{array}{l}75.71 \\
(8.70)\end{array}$ & 110.67 & 7.95 & 6.39 & 2.36 & 7.71 & 1.46 & 104.28 \\
\hline $\mathbf{V}_{1} \mathbf{T}_{3}$ & $\begin{array}{l}74.76 \\
(8.65)\end{array}$ & 103.67 & 10.10 & 5.39 & 2.61 & 8.81 & 1.66 & 118.57 \\
\hline $\mathbf{V}_{1} \mathbf{T}_{4}$ & $\begin{array}{l}72.38 \\
(8.51)\end{array}$ & 107.67 & 9.09 & 6.49 & 2.69 & 8.16 & 1.65 & 117.85 \\
\hline $\mathbf{V}_{1} \mathbf{T}_{5}$ & $\begin{array}{l}74.28 \\
(8.62)\end{array}$ & 111.67 & 9.18 & 6.17 & 2.99 & 8.26 & 1.63 & 113.33 \\
\hline$V_{1} T_{6}$ & $\begin{array}{l}74.76 \\
(8.65)\end{array}$ & 110.00 & 8.74 & 7.03 & 2.15 & 8.25 & 1.59 & 113.33 \\
\hline $\mathbf{V}_{2} \mathbf{T}_{1}$ & $\begin{array}{l}72.85 \\
(8.53)\end{array}$ & 109.33 & 7.57 & 5.83 & 2.09 & 8.55 & 1.34 & 100.49 \\
\hline $\mathbf{V}_{2} \mathbf{T}_{2}$ & $\begin{array}{l}73.80 \\
(8.59)\end{array}$ & 109.33 & 7.90 & 5.35 & 2.11 & 7.98 & 1.74 & 130.82 \\
\hline $\mathbf{V}_{2} \mathbf{T}_{3}$ & $\begin{array}{l}76.19 \\
(8.73)\end{array}$ & 101.67 & 8.53 & 6.11 & 2.13 & 9.39 & 1.75 & 131.58 \\
\hline $\mathbf{V}_{2} \mathbf{T}_{4}$ & $\begin{array}{l}77.14 \\
(8.78)\end{array}$ & 105.67 & 9.33 & 5.45 & 2.30 & 8.98 & 1.65 & 124.06 \\
\hline $\mathbf{V}_{2} \mathbf{T}_{5}$ & $\begin{array}{l}76.19 \\
(8.73)\end{array}$ & 109.00 & 8.17 & 6.54 & 2.78 & 8.25 & 1.54 & 116.04 \\
\hline$V_{2} T_{6}$ & $\begin{array}{l}77.14 \\
(8.78)\end{array}$ & 108.67 & 8.51 & 5.48 & 2.48 & 8.65 & 1.39 & 102.98 \\
\hline $\mathbf{V}_{3} \mathbf{T}_{1}$ & $\begin{array}{l}73.80 \\
(8.59)\end{array}$ & 107.33 & 8.84 & 5.18 & 2.18 & 8.99 & 1.30 & 99.99 \\
\hline $\mathbf{V}_{3} \mathbf{T}_{2}$ & $\begin{array}{l}75.23 \\
(8.67)\end{array}$ & 107.67 & 9.33 & 5.60 & 2.28 & 9.71 & 1.24 & 95.12 \\
\hline $\mathbf{V}_{3} \mathbf{T}_{3}$ & $\begin{array}{l}77.14 \\
(8.78)\end{array}$ & 100.67 & 10.18 & 6.14 & 3.01 & 9.77 & 1.65 & 126.92 \\
\hline $\mathbf{V}_{3} \mathbf{T}_{4}$ & $\begin{array}{l}76.19 \\
(8.73)\end{array}$ & 104.33 & 8.90 & 6.45 & 2.88 & 9.31 & 1.60 & 123.07 \\
\hline $\mathbf{V}_{3} \mathbf{T}_{5}$ & $\begin{array}{l}74.76 \\
(8.65)\end{array}$ & 106.00 & 8.66 & 6.43 & 2.94 & 9.48 & 1.61 & 123.84 \\
\hline$V_{3} T_{6}$ & $\begin{array}{l}72.85 \\
(8.53)\end{array}$ & 107.33 & 8.17 & 5.79 & 2.24 & 8.75 & 1.37 & 105.38 \\
\hline CD at $5 \%$ & 0.16 & NS & 1.07 & 0.52 & 0.41 & 0.69 & 0.18 & 13.56 \\
\hline
\end{tabular}

Figures in parenthesis shows the square root transformed values 
The weight of bulblets produced also differed significantly due to different treatments. Greater diameter of bulblets having heavier bulblets. Maximum fresh weight of bulblets/scale $(1.57 \mathrm{~g})$ was found in cultivar 'Frans Hals'. It was found to be at par with weight of bulblets obtained in 'Batistero' $(1.55 \mathrm{~g})$ and minimum fresh weight of bulblets/scale $(1.46 \mathrm{~g})$ was foundin cultivar 'UHFS LA Lily Collection 1' (Table 1). The varietal variability could be attributed to the genotypic differences between them which is supported by earlier studies by Singh (12); Sharma et al., (11); Lyngdoh (5). Among calcium nitrate doses maximum fresh weight of bulblets/scale $(1.69 \mathrm{~g})$ was obtained when calcium nitrate was applied to the scales at the rate of $10 \mathrm{~g} / \mathrm{m}^{2}$.Increased fresh weight of the bulblets obtained in this treatment corresponds to the maximum leaf length and respective increased bulblet diameter in this treatment. Longer leaves contributed to the more carbohydrate accumulation and their channelization into the bulblets thus increasing their weight. Interaction (Table 2) effect of cultivars with calcium nitrate doses shows that maximum fresh weight of bulblets/scale $(1.75 \mathrm{~g})$ was recorded in cultivar 'Frans Hals', in cultivar 'Batistero' maximum fresh weight of bulblets/scale (1.66 g) and in 'UHFS LA Lily Collection 1', maximum bulblet weight $(1.65 \mathrm{~g})$ was obtained with calcium nitrate at $10 \mathrm{~g} / \mathrm{m}^{2}$. Maximum propagation index (117.66\%) was recorded in cultivar 'Frans Hals'. It was, however, found to be at par with propagation index of 'UHFS LA Lily Collection 1' (112.39\%). Cultivar 'Batistero' recorded minimum $(110.67 \%)$ propagation index (Table 1). The genotypic variation among cultivars is reflected in the propagation index also with maximum of it recorded in cultivar 'Frans Hals' followed by 'UHFS LA Lily Collection 1' and 'Batistero'. Among different calcium nitrate doses, maximum propagation index (125.69\%) observed in 10 $\mathrm{g} / \mathrm{m}^{2}$ (Table 1). Interaction (Table 2) effect of cultivars with calcium nitrate doses shows that maximum propagation index $(131.58 \%)$ was observed in cultivar 'Frans Hals', maximum propagation index $(118.57 \%)$ in cultivar 'Batistero' and in case of 'UHFS LA Lily Collection 1' (126.96\%) was obtained with $10 \mathrm{~g} / \mathrm{m}^{2}$ application of calcium nitrate.

\section{References}

1. Choi, J. M., Lee, K. H., and Lee, E. M. 2005. Effect of Calcium Concentrations in Fertilizer Solution on Growth of and Nutrient Uptake by Oriental Hybrid Lily 'Casa Blanca'. Acta Horticulturae. 673: 755-760.

2. Jong Won, L., Tae Joung, K., Ju Hyoung, K., Hak Hyoun, K., Cheol Hee, L., Kwan Soon, C., and Kee Yoeup, P. 1999. Effect of priming on seed germination and seedling growth of Lilium formolongi. Korean Journal of Horticultural Science and Technology. 17(2): 136-137.

3. Karimi, V., Hatamzadeh, A., Asil, M. H., and Samizadeh, H. 2012. An evaluation of effects of calcium nitrate and IBA on quality and quantity of two cultivars of lily cut flower. Iranian Journal of Horticultural Science. 43(1): 79-89.

4. Krause, J., 1996. Reproductive ability of some Lilium longiflorum varieties propagated from bulb scales. Prace-Z Zakresu- Nauk-Rolniczych. 81: 267-273.

5. Lyngdoh, A., 2010. Effects of substrates on the propagation of hybrid lilies through scaling. M.Sc. Thesis, Dr. Y. S. Parmar University of Horticulture and Forestry, Nauni, Solan (H.P), India.

6. Matsuo, E., and Arisumi, K. 1979. Varietal differences in the development of the scale bulblet in the Easter lily. Memories of the Faculty of Agriculture, Kagoshima University. 15: 79-85.

7. Nair, S. A., and Shiva, K. N. 2003. Performance of selected gladiolus 
(Gladiolus floribundas) varieties under Bay island conditions. Indian Journal of Agricultural Sciences. 73(7): 397-398.

8. Rani, N., Kumar, R., and Dhatt, K. K. 2005. Studies on the effect of nitrogen levels and growing media on growth, flowering and bulb production of Lilium cultivars. Journal of Ornamental Horticulture. 8(1): 36-40.

9. Safiullah, and Ahmed, M. J. 2001. Evaluation of exotic cultivar of gladiolus (Gladiolus grandiflorus) under Rawalkot conditions. Sarhad Journal of Agricultural Sciences. 7(2): 171-174.

10. Seyedi, N., Mohammadi Torkashvand, A., and Allahyari, M. S. 2013. Investigating of the effects of calcium concentration under hydroponic conditions on quantitative and qualitative growth of Lilium 'Tresor'. Journal of Ornamental and Horticultural Plants. 3(1): 19-24.

11. Sharma, P., Sharma, Y. D., Dhiman, S. R., and Gupta, Y. C. 2007. Effect of growth regulators and growing media on propagation of Oriental lily hybrids through scaling. Journal of Ornamental Horticulture 10(3): 148-152.

12. Singh, A., 2002. Effect of position, plant growth regulators and growing media on bulblet production of Lilium Hybrids. Ph.D. Thesis, Dr. Y. S. Parmar University of Horticulture and Forestry, Nauni, Solan (H.P), India.

13. Treder, J., 2008. Effects of cocopeat and fertilization on the growth and flowering of Oriental lily 'Star Gazer'. Journal of Fruit and Ornamental Plant Research. 16: 361-370.

\section{How to cite this article:}

Anu Bala, Puja Sharma, S.R. Dhiman and Gupta, Y.C. 2019. Effect of Calcium Nitrate on Propagation of LA Hybrid Lilies through Scaling. Int.J.Curr.Microbiol.App.Sci. 8(01): 20912098. doi: https://doi.org/10.20546/ijcmas.2019.801.219 